\title{
Routines, Capabilities and Innovation in the Brazilian Wine Industry
}

\author{
André Cherubini Alves',Aurora Carneiro Zen², Antônio Domingus Padula ${ }^{3}$
}

\begin{abstract}
As environments become more competitive and change, firms need to look for new ways of competing by implementing changes and innovations aiming at improving or even building new capabilities. Through multiple case studies, we examine the relationship between routines, capabilities and innovation seeking to identify the changes and innovations that have occurred along the trajectory of two wine producing firms in the Serra Gaúcha of Rio Grande do Sul, Brazil. The results indicate that both companies submitted changes/innovations in routines and capabilities, however, the different strategies and decisions made led to totally different outcomes in terms of size, growth and market-share.
\end{abstract}

Keywords: Routines; capabilities; dynamic capabilities; innovation; change.

\footnotetext{
' Assistant Professor. School of Economics and Administration, University of the Rio dos Sinos Valley, Av. Unisinos, 950 Cristo Rei, São Leopoldo, RS, 93.022-000, Brazil. Phone: +55 (5I) 359I I I22. Email: andrecherubin@unisinos.br

${ }^{2}$ Associate Professor. Business Administration, Economics and Accounting School, Pontifical Catholic University of Rio Grande do Sul Avenida Ipiranga, 668I, Prédio 50 Partenon, Porto Alegre, RS, 90.619-900, Brazil. Phone: +55 (5I) 3320 7876. Email: aurora.zen@pucrs.br ${ }^{3}$ Full Professor. Management School, Federal University of Rio Grande do Sul PPGA/EA/UFRGS, Rua Washington Luiz, 855 Porto Alegre, RS, 90.010-000, Brazil Phone: +55 5I 3308 3536. Email: adpadula@ea.ufrgs.br
} 


\section{Introduction}

Find the reasons why firms succeed in the midst of intense competition is among the main motivations of the management research agenda. It is possible to find in literature the notion that firms survive when they are able to produce value efficiently and profitably and to this end, it must know-how to do something better than others. Competition emerges in this context dictating the pace at which firms must find new ways of creating value by acquiring and applying new knowledge, both external and internally developed, aimed at improving products and processes or developing new ones via the innovation.

Capabilities and dynamic capabilities are terms often used to describe what the firm is able to do and how it seeks and implements changes and innovations, so sources of sustainable competitive advantage. Several studies have argued that capabilities are composed of a set of 'routines' which is one of the central concepts in evolutionary theory of Nelson and Winter (Grant, 1991; Chandler, 1992; Collis, 1994, Winter, 2000). Thus, it is possible to identify a relationship between routines, capabilities and innovation, however, few studies explore this relationship, because they usually focus on one of these elements.

This study aims to examine the relationship between routines, capabilities and innovation, seeking to identify changes and/or innovations that have occurred along the trajectory of the firm and how these changes altered their routines and capabilities. To that end, we conducted a case study in the wine industry in two enterprises located in the Serra Gaúcha of Rio Grande do Sul. Brazil is the 14th wine producer in the world ranking as of 2007. The introduction of new technology was in the years 70 and 80 with the arrival of international companies decided to invest in the fine wine market in the country. In the 90 s the Brazilian government opened its boarders to international competition. The consequent entry of imported products in the market made intense pressure over the domestic industry which forced the need of various actions of restructuring (Alievi and Fensterseifer, 2007).

The new competitive landscape of the Brazilian wine industry presents improvement of various aspects of production through new equipments and technology as well as marketing strategies looking for a best understanding customers preferences in addition to the use of mass marketing. On the other hand there are still more conservative companies whose strategy is focused on producing wines by hand, on small properties geared primarily to artisanal production. These differences create an apparent dichotomy between modes of production and marketing of companies investing in producing in large quantities and are looking for growth through multiple paths of change/ innovation, and small businesses that follow sustainable production and traditional commercialization strategies, apparently averse to altering its way of doing things.

This article is structured into five parts. After this introduction, the second section presents a literature review on capabilities, routines and innovation. The third part describes the methodological procedures adopted. Subsequently, it will be shown a brief panorama of the wine sector. The fifth section presents the analysis and discussion of the data. Finally, the conclusions of the work.

\section{Capabilities, Routines and Innovation}

The research on capabilities has not reached maturity (Wang and Ahmed, 2007). Several authors support the notion that sustaining competitive advantage of firms resulting from the construction of capabilities (Hayes, 1985; Prahalad and Hamel, 1990; Stalker, Evans and Shulman, 1992). However, their definitions remain ambiguous and variable.

To Dosi, Nelson and Winter (2000), the importance of understanding capabilities is in the fact the term represents the expression of the firm's "know-how" on doing certain things, such as, producing cars or computers, or flying from one continent to another. In the authors words, "to be capable of something is to have a generally reliable capacity to bring that thing about as a result of intended action" (p.2).

The term 'capabilities' was coined by Richardson (1972) who defined it as knowledge, capabilities and experience of the firm. However, it is possible to find in the literature several a relation between capabilities and the term 'routines' which is one of the central concepts of the evolutionary theory of Nelson and Winter (1982) (Grant, 1991; Chandler, 1992; Collis, 1994; Peng, Schroeder and Shah, 2007). 
The firm executes a series of interrelated activities (routines) based on both explicit and tacit knowledge which express the firm's capabilities (Nelson and Winter, 1982). As Grant (1991), the set of capabilities of the organization is organized into an integrated hierarchy of routines executed in different functional areas of business such as, operational, research and development (R\&D) and sales. Chandler (1992) argues that the notion of hierarchy of organizational routines is key to the concept of organizational capability.

On the other hand, to face competitive markets, firms need to seek ways to improve their capabilities. Within this context, Nelson (1991) and Teece, Pisano and Shuen (1997) develop the theory of 'dynamic capabilities' of the firm that takes into account the evolutionary theory proposed by Nelson and Winter (1982). Dynamic capability is defined as "the ability of firms to integrate, build and reconfigure internal and external competences to address changing environments"(Teece, Pisano and Shuen, 1997, p.516) and therefore a source of sustainable competitive advantage.

Some authors discuss the relevance of dynamic capabilities for the maintenance of sustainable competitive advantage. Eisenhardt and Martin (2000) argue that dynamic capabilities only ensure sustainable competitive advantage when are implemented sooner, more astutely, or more fortuitously than competition and only through specific resources. The authors believe that these capabilities become irrelevant over time and only have value when combined with greater resources VRIN (valuable, rare, inimitable and non-replaceable), thus reinforcing the conceptual framework of the Resource-Based View (RBV).

Wang and Ahmed (2007) discuss the resources and capabilities of the firm in a hierarchical order where the resources are the foundation of the firm and the basis for its capabilities and core capabilities. Capability is the ability to pool resources to achieve a desired goal and the core-capabilities are the set of resources and capabilities that are strategically important for the generation of competitive advantage at some point. However, in a dynamic environment, resources and capabilities VRIN not persist for long and thus can not be a source of sustainable competitive advantage. Thus, the dynamic capabilities are seen as elements of 'third-order' emphasizing the behavioral orientation of the firm constant pursuit of the renewal, reconfiguration and re-creation of resources, and capabilities to address the environmental change.
In this sense, dynamic capabilities can be understood as the "ultimate organizational capability that conduct performance in the long run" (Wang and Ahmed, 2007). Although capabilities are related to the term routines, Zollo and Winter (2002) consider the dynamic capability as a learned and stable pattern of collective activities through which the organization generates and modifies its operating routines systematically to improve their efficiency.

On the other hand, if routines constitute the firm's capabilities, the relationship between dynamic capabilities and routines is not as clear. Peng, Schroeder and Shah (2007) argue that the ability to improve and innovate comes from a set interrelated organizational routines. Eisenhardt and Martin (2000) suggest that the ability to develop new products/ processes comes from a set of specific and identifiable organizational routines. Bessant and Francis (1999) note that the capability improvement is a broad organizational process of incremental and sustainable innovations which are essentially a set of routines. The following section aims to clarify the term routines of Nelson and Winter (1982) and establish that relationship with change/innovation.

\section{I Capabilities and Routines}

As Dosi, Nelson and Winter (2000), routines are seen as units of organized activities with a repetitive nature and can be understood as 'building blocks' of capabilities. For Becker (2009), one of the fundamental aspects of the concept of organizational routines is to provide the means to describe organizational behavior and how it changes. The focus given to the routines is linked to the fact it assist in the analysis of the micro-evolutionary process (Nelson and Winter, 1982).

As Nelson and Winter (1982), being cable means to meet the requirements necessary to perform these routines. Among the three necessary conditions are: I) that individuals in the organization are provided with the necessary knowledge regarding the repertoire of possible actions, 2) there are specialized plants and equipment (technical-systems) whose ability to handle them is contained in the individual and collective repertoire, and 3 ) that there are inputs that will be used during the processes. So, if routines are the building blocks of capabilities, knowledge and individual skills, equipment or systems and some specific technical inputs are the building blocks of routines. Thus, routines emerge from a repertoire of alternatives within the organization. They do not occur at all times without ceasing, but when triggered by internal or external signals and occur within a certain pattern. 
The behavior that seeks to change and innovation emerges from the firm's set of heuristics that change the content of the routines, i.e. the daily search for resolution of problems that arise as individuals in the organization are faced with random internal and external events. This behavior is comes from a second set of routines called 'searches' (Nelson and Winter, 1982).

The search routines are activities of the firm that are associated with the evaluation of current routines that may lead either to its modification as to the most drastic changes or even replacement. Some of these activities can be partly routinized and predictable, but may also have a random or stochastic character. In this sense, to simply exist in competitive environments, firms need to be able to promote a greater or lesser extent changes in its routines.

What triggers the process of change can be a reaction to external and internal factors or as part of a deliberate strategy. The successful outcome of the shift can be seen in innovations or improvements in products and services, internal processes, marketing strategies or even the firm's business model. To this end, the firm needs to establish ways to seek and apply new knowledge in their internal processes, seeking some level of change in order to create value. The dynamic capability of the firm arises from the way it searches and alters its internal routines in order to do so.

\subsection{Innovation}

The search for competitive advantage requires companies to constantly need to seek ways to offer value. As competition intensifies this search necessarily involves innovation. In literature, the concept of innovation is mainly associated with changes in products and processes involving the use, application and transformation of scientific and technical knowledge in solving problems related to production and marketing, in an attempt to profit (Freeman, 1994). Therefore, in order to innovate, the firm typically needs to combine different types of resources such as production-related knowledge, capabilities and industrial facilities, market knowledge, an efficient distribution system, financial resources, among others (Fagdeberg, 2004). The commercial application of the invention makes it an innovation (Rothwell and Gardiner, 1985). In such cases, the result of innovation is a new technology solution, but it is possible to identify other dimensions of innovation. According to the approaches of Schumpeter (1934) and Francis and Bessant (2005) innovation can be classified into specific types.

According to the classification of Schumpeter (1934), the corporate profit emerge from the capacity that the entrepreneur has to make "new combinations". These new combinations go beyond the dichotomy of product/process comprising the following five cases: introduction of a new well, a new method of production, opening a new market, the opening source of supply of raw materials or semi-manufactured goods regardless of the fact that this source already existed or had to be created and the establishment of a new organization of any industry.

Similarly, Francis and Bessant (2005), develop a model in which innovation can be achieved in four broad areas. The four P's are: PI innovation in introducing or improving products; $\mathrm{P} 2$ innovation in introducing or improving processes; P3 innovation in defining or redefining the positioning of products/services of the firm, and P4 innovation in defining or redefining the dominant paradigm of the firm in terms of shared values and/or of the company's business model and how it is structured. Both concepts have some similarities in content can be contrasted according to Table I.

\begin{tabular}{|ll|l|}
\hline Francis and Bessant (2005) & Schumpeter (1934) \\
\hline $\mathrm{A}$ & $\begin{array}{l}\mathrm{P}_{1} \text { Product/Service: innovation-change } \\
\text { in what is offered }\end{array}$ & $\begin{array}{l}\text { 1) The introduction of a new good. } \\
\text { 4) The opening of a new source of supply of raw } \\
\text { materials. }\end{array}$ \\
\hline $\mathrm{B}$ & $\begin{array}{l}\mathrm{P}_{2} \text { Process: innovation-change in the } \\
\text { ways in which it is created and delivered }\end{array}$ & $\begin{array}{l}\text { 2) The introduction of a new method of } \\
\text { production. }\end{array}$ \\
\hline $\mathrm{C}$ & $\begin{array}{l}\mathrm{P}_{3} \text { Position: innovation-change in the ways in } \\
\text { which it is created and delivered }\end{array}$ & 3) The opening of a new market. \\
\hline $\mathrm{D}$ & $\begin{array}{l}\mathrm{P}_{4} \text { Paradigm: innovation-change in the } \\
\text { underlying mental models surrounding it } \\
\text { (mental and business models) }\end{array}$ & $\begin{array}{l}\text { 5) The carrying out of the new organization of } \\
\text { any industry. }\end{array}$ \\
\hline
\end{tabular}

Table I - Comparative between the approaches to innovation of Francis e Bessant (2005) e Schumpeter (1934) 
The most visible applications of innovation is the one that results on new products or services. The literature on new product development capability recognizes this as an important source of competitive advantage (Cooper, 200I; Stalker, Evans and Schulman, 1992; Wheelwright, Clark, 1992; Christensen, 2003). According to the typology of Schumpeter (1934), innovation/change products may be related to new and/or different sources of raw material or as these sources are combined in different ways. To Henderson and Clark (1990), products are based on the components (or modules) that are part of the product and how they are combined. This idea creates a matrix of four types of innovation: incremental, modular, architectural and radical.

In this sense, product innovations often lead to innovations in both product and processes. Utterback and Abernathy (1975), for example, show that rates of innovation in products and process are related to the development stage of the technology, in other words, product innovation arises from new uncoordinated procedures and as it is introduced to the market cause changes in manufacturing processes in order to achieve economies of scale. Among the historical examples of innovation/ change in manufacturing processes is the development of the Toyota Production System that has been widely disseminated as lean manufacturing.

The innovation in markets may be related to the introduction of products that are new to a given market, such as a new country in which this product has not yet been made, for example. According to Anderson and Gatignon (2004), new markets do not emerge nor appear, but are created by activities of the firm. This occurs when the firm correctly senses whether by accident or by design a latent need and communicate its solution to that need. "The mere marketing activity, not only can create new markets, but can alter the way markets function" (Anderson and Gatignon, 2004, p.404). This is an idea also supported by Francis and Bessant (2005) under the name of innovation in position. For the authors, innovation can happen in a position where the perception of a product or process is changed in a particular context (Francis and Bessant, 2005).
Besides the four possibilities for change and innovation described above (products, raw materials, markets and processes), Schumpeter (1934) describes another category subject to change and innovation in the form of new combinations: the organization of the industry. The examples cited by the author involve the formation of oligopolies or monopolies, or inversely, the fragmentation of these positions. Some economic theories can explain the reasons that lead some industries to organize themselves in a certain way based on the holistic view of the firm and the decisions around make or buy or cooperate in order to reduce transaction costs (Coase, 1937, Williamson, 1985; Richardson, 1972). Moreover, the need for interfirm cooperation can result in local production systems or clusters (Porter, 1998).

Based on the discussion above around of capabilities, routines and types of innovation, it was developed an analytic framework aiming at providing an integrated view of how the innovation process occurs within and outside the firm (Figure I).

The framework provides a visual way for understanding what constitutes operational capabilities and how the search for different types of innovation/change may alter the content of these capabilities manly by altering the routines Miolo the capabilities of the firm. Dynamic capability of the firm is the ability to integrate, build, renew, modify and adapt routines through a learning process.

As for this research, we conduct a micro-analysis of three types of capabilities: Production Capabilities, Marketing Capabilities and R\&D Capabilities. 


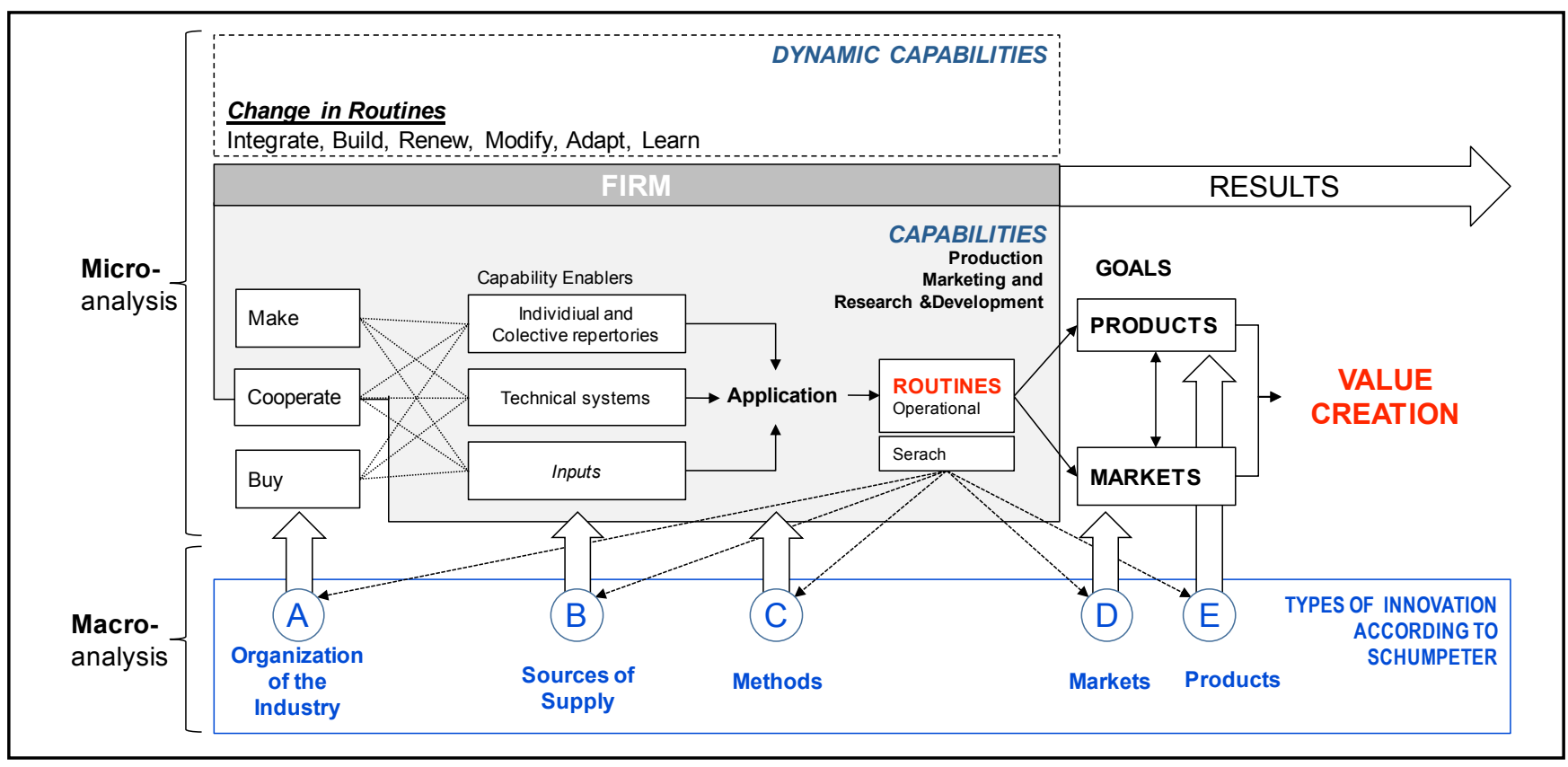

Figure I - Analytical framework for the integrated analysis of routines, capabilities and types of Innovation

\section{Research Procedures}

The present study utilized the method of multiple case study (Yin, 200I). According to Sterns, Schweickhardt and Peterson (1998), the case study is capable of generating a robust and comprehensive array of knowledge about complex social and economic phenomena, dynamic and highly interdependent. We selected two wineries located in the city of Bento Gonçalves, part of the wine cluster's in Serra Gaúcha, Rio Grande do Sul. Apart from being family businesses founded in the same period, the two wineries sustain different positions, sizes and competitive strategies. Data were collected in the second half of 2009 from primary and secondary sources. There were extensive interviews with members of companies and representatives of institutions related to the sector, and documentary analysis of previous research and visits carried out in wineries.

Data analysis occurred in two steps, as shown in Figure 2. At first we carried out a macro analysis of the historical evolution of the companies to identify the main events by classifying them according to the types of change and innovation and capabilities developed or seen developed. In the second stage developed a microanalysis capabilities of fine wine production, marketing and R\&D firm for a description and analysis of their underlying routines. The specific capabilities and routines analysed are showed in Table 2.

\begin{tabular}{|lll|}
\hline Capabilities & Routines & Cassification \\
\hline $\begin{array}{c}\text { Production: } \\
\text { Viticulture }\end{array}$ & Soil and Plants Management; & \\
Vinification & Process of receiving and de-stemming grapes; & Operational \\
& Conduction system, fermentation and maceration, & Operational \\
& Maturation Systems; & Operational \\
& Bottling process; & Operational \\
& Aging Process in Caves. & Operational \\
& Marketing Research; & Operational \\
\hline Marketing & Communication, promotion and advertising actions Marketing & Search \\
& Strategies and distribution & Operational \\
& Research on Viticulture; & Operational \\
\hline Research \& & Research on Vinification, & Search \\
Development & Research using alternative materials (packaging, closures, etc.) & Search \\
& Product Development. & Search \\
& & Operational \\
\hline
\end{tabular}

Table 2 - Capabilities and underlying Routines Analyzed 


\section{The Wine Industry}

According to the Global Wine Monitor (2009), by 2008, the five largest producers in the world were Italy (4.7 billion liters), France (4.4 billion liters), Spain (3.7 billion liters), the United States (2.5 billion liters) and Argentina (I.5 billion liters). Together these countries counted for $62 \%$ of the wine produced worldwide. Australia was the sixth country in production with I.3 billion liters in 2008 , behind Argentina counting for $5 \%$ of world's production. Although wine is one of the world's oldest types of beverages relatively simple to produce resulting from a natural process of alcoholic fermentation of sugars contained in grapes, most of technological, commercial and structural changes in the industry are recent with the entrance of new countries participating in the global market.

The wine industry can be divided into two groups of producing countries that can be characterized not only for its different geographical dispositions but also by the different philosophies of production and commercialization. The Old World consists of countries of Europe such as France, Italy and Spain, traditional in wine production. Moreover, it is verified in recent decades the growing involvement of new producer countries such as Australia, Chile, Argentina, South Africa and Brazil. This second group was called New World wine.

Until the late nineteenth century, the wine industry was dominated by the Old World countries, who headed the world market in the production and consumption of the product. However, natural and demographic factors such as population growth in cities and crises of production resulting from pests and diseases that devastated entire crops lead to a steep decline in supply and the emergence of falsification of products by opportunists willing to meet the high demand. To prevent these fraudulent actions, regulations and appellations of origins were created to restrict certain practices for wine production in order to ensure quality (UNWIN, 1996). Many of these regulations characterize much of how wine is produced in Europe.

During the 60 years after the Second World War a number of technological innovations in viticulture and winemaking have come up with aiming at reducing production costs, variation and ensuring quality for emerging markets. During the 70s the international landscape has undergone changes with the arrival of the New World wineries increasing production and exports to the United States and England (Anderson, 2004). These markets required high volumes of production, lower prices, easier to drink products and mass marketing strategies. Given its tradition and regulations, the countries of the Old World could not provide all of them.

Thus, there were developed two standards of competition in the sector. Wine from the Old World seeking to enhance the features of terroirl, ie, the wine should reflect the expression of the land from which it was produced. On the other hand, the New World wine seeks to provide an agricultural product, given consumers' preferences. Thus, the characteristics of the region became secondary for New World wines. However, in recent years, there is a trend of convergence of the models, in which the New World producers have sought to enhance the product's origin and the wineries of the Old World have developed some products more aligned to the demands of consumers.

In the 70s Brazil entered the route of multinational companies that followed a trend of exploring new less traditional places in the wine world. These companies brought with them new technologies and established purchase relationships with growers which later led to a crisis of supply and demand. In the 90 s, trade liberalization and intensified competitiveness imposed extreme changes in the organization of the sector. New companies entered the market for fine wine production. Some were motivated by the need to find an outlet for surplus grapes, others motivated by growth prospects generated by the heating demand arising from factors such as materials about the benefits of wine and the French paradox.

The 2000s represented advances in the Brazilian viticulture methods attempting to improve the quality of the grape. On the other hand, the scenario has become even more competitive as it is marked by a reduction in wine consumption in traditional countries and the entry of new producer countries. In the Brazilian context, the competition became even more aggressive with neighboring countries such as Argentina and Chile. The consumption of imported wine was $75 \%$ in the Brazilian market during the year 2008, which has shown the need for wineries to become more competitive. 


\section{Results}

\section{I Miolo Winery}

The Miolo Winery was founded in 1989 and has undergone major changes since its then. Today it constitutes the Miolo Wine Group managing six national projects in different regions of the country and three joint ventures in Argentina, Chile and Spain. As the institutional informative (Miolo, 20I0), the company owns about $40 \%$ marketshare in the commercialization of fine wines among the wineries of Brazil. The various national projects are responsible for drawing about 100 labels. The company is Brazil's largest exporter of wine and is among the three leading producers of sparkling wine, with a $15 \%$ stake in the market. Around 12 million liters of fine wine are produced each year in an area of I, 150 hectares of vineyards (all grapes specific for fine wines) that use vertical system of conduction (trellis). Besides the vineyards, the company also coordinates the production of grapes on 330 hectares belonging to 60 families in the Serra Gaúcha.

\section{I.I Macro-analysis}

In two decades the company has expanded due to a large number of changes ranging from the improvement in the ability of grape production and winemaking, fine quality, through the improvement of its processes of distribution, communication strategies, marketing and development products. These changes were accomplished by improving both their own capabilities and by establishing strategic alliances with companies in the wine industry nationally and internationally. Table 2 shows the evolution of the company during these two decades in terms of growth in the area coordinated by the firm produced.

\begin{tabular}{|c|c|c|}
\hline Year & Main Events & Types of innovation/change \\
\hline \multirow{7}{*}{ 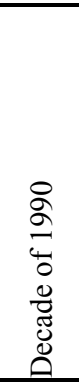 } & Construction of the structure to winemaking and bottling & PROCESS \\
\hline & Launch of the first wines & PRODUCTS \\
\hline & Structuring of country wise distribution channels & PROCESS /MARKETS \\
\hline & Beginning integration with grape-grower families & \multirow{2}{*}{$\begin{array}{c}\text { ORGANIZATION OF THE } \\
\text { INDUSTRY }\end{array}$} \\
\hline & Start of first partnership with another winery for technical assistance & \\
\hline & Start of quality production projects & PROCESS \\
\hline & Start of vineyards conversion to better quality systems & PROCESS \\
\hline \multirow{8}{*}{ 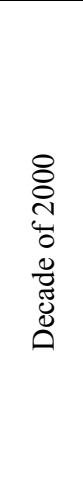 } & Introduction of new facilities and continuous refine tuning and process standardization & PROCESS \\
\hline & Stepping on the rigor of quality management with families of integrated producers & PROCESS \\
\hline & Acquisition of 4 new properties & PROCESS \\
\hline & Launch of 4 new lines of products & PRODUCTS \\
\hline & $\begin{array}{l}\text { New organizational arrangements, new joint-ventures and formations of the Miolo } \\
\text { Wine Group }\end{array}$ & $\begin{array}{l}\text { ORGANIZATION OF THE } \\
\text { INDUSTRY }\end{array}$ \\
\hline & Expansion of national distribution channels & PROCESS/ MARKETS \\
\hline & Beginning the process of expanding into new international markets and export growth & $\begin{array}{c}\text { PROCESS/ } \\
\text { ORGANIZATION OF THE } \\
\text { INDUSTRY / MARKETS }\end{array}$ \\
\hline & Professionalization and departmentalization of the company & PROCESS \\
\hline
\end{tabular}

Table 2 - Macro-analysis of Miolo Winery 


\section{I.2 Micro-analysis}

Table 3 presents a summary of capabilities and routines of the Miolo winery that showed changes in the last four years. The analysis considered the capabilities in viticulture, marketing and research and development.

\begin{tabular}{|c|c|}
\hline $\begin{array}{l}\text { CAPABILITIES and underlying } \\
\text { ROUTINES }\end{array}$ & Change in routines in the last four years?? \\
\hline \multicolumn{2}{|l|}{ VITICULTURE } \\
\hline \multirow[t]{2}{*}{ Soil and Plants Management } & $\begin{array}{l}\text { The changes involve tightening of controls and systems resulting from the } \\
\text { implementation of food safety standards, such as traceability and carefully } \\
\text { monitoring the maturity and quality of grapes. }\end{array}$ \\
\hline & $\begin{array}{l}\text { The changes involve tightening of controls and systems resulting from the } \\
\text { implementation of food safety standards such as traceability and carefully } \\
\text { monitoring the maturity and quality of grapes. }\end{array}$ \\
\hline \multicolumn{2}{|l|}{ VINIFICATION } \\
\hline $\begin{array}{l}\text { Process of receiving and de- } \\
\text { stemming grapes }\end{array}$ & $\begin{array}{l}\text { The classification and separation of the grapes before they arrive starting the } \\
\text { winery, with a selection of clusters already in their own vineyard. }\end{array}$ \\
\hline \multirow[t]{2}{*}{$\begin{array}{l}\text { Conduction system, fermentation } \\
\text { and maceration }\end{array}$} & $\begin{array}{l}\text { Utilization of hydraulic pumps for the transport of wine more smoothly. (The } \\
\text { grape itself is never pumped due to the gravitational action-oriented setup). }\end{array}$ \\
\hline & Traceable tanks and automated temperature control systems \\
\hline Maturation Systems & $\begin{array}{l}\text { Changes in supply. Purchase of the barrels apart to be assembled in Brazil. } \\
\text { (however did not modify a specific routine production) }\end{array}$ \\
\hline Bottling process & Ampliou e dividiu as linhas de acordo com os tipos de produto. \\
\hline Aging Process in Caves & Remained unchanged \\
\hline \multicolumn{2}{|l|}{ MARKETING } \\
\hline Marketing Research & $\begin{array}{l}\text { Reorganization of marketing department after the formation of Miolo Wine } \\
\text { Group. } \\
\text { Expanded its offices into six branches. }\end{array}$ \\
\hline \multirow{2}{*}{$\begin{array}{l}\text { Communication, promotion and } \\
\text { advertising actions }\end{array}$} & Altered structure, hired professional executives. \\
\hline & Has sought to broaden participation in the world. \\
\hline \multirow{2}{*}{$\begin{array}{l}\text { Marketing Strategies and } \\
\text { distribution }\end{array}$} & Expansão e novas estratégias de relacionamento. \\
\hline & Expanding markets. And today has a range of export to 23 countries \\
\hline \multicolumn{2}{|l|}{ RESEARCH AND DEVELOPMIENT } \\
\hline Research on Viticulture & $\begin{array}{l}\text { Began development of vineyards to sustainable concepts with organic and } \\
\text { biodynamic. }\end{array}$ \\
\hline Research on Vinification & $\begin{array}{l}\text { The laboratory has received new machines that help the perception and sensitivity } \\
\text { of the winemaker tasting. }\end{array}$ \\
\hline $\begin{array}{l}\text { Research using alternative materials } \\
\text { (packaging, closures, etc.) }\end{array}$ & Remained unchanged. Continues to do. \\
\hline Product Development & $\begin{array}{l}\text { Improvement and development of new wines with methods not yet used in the } \\
\text { company. Ex: Sesmarias Wine. }\end{array}$ \\
\hline
\end{tabular}

Table 3 - Micro-analysis of Miolo Winery 
With respect to the production capability in viticulture, the company produces and also has grape purchase arrangements with the integrated families whose production are coordinated and controlled by direct supervision and monitoring of Miolo's agricultural technicians. The biggest change in recent years occurred in viticulture through the conversion of vineyards of the integrated families into the trellis conducing system 2 and the qualification of the processes to conform to international standards. Both changes occurred in Plants and Soil Management System and conversion of vineyards have changed the routines of viticulture capability since changed the application of knowledge and technical systems.

The company's winemaking capabilities were also changed to obtain the certifications. In 2006 an engineer was hired to deal with food hygiene issues such as the canteen, handling procedures, training of staff. In 2008, the company obtained the certification of food safety and quality.

Over the past four years, there have been more rigorous process of classification of raw material, which starts before the grapes come in the wake of the canteen. With respect to the winemaking process, the changes involved modification of the methods for driving the grapes by the tanks. The company uses the method of driving by gravity and pumps to transport the wine more smoothly so far as to dump the grapes.

It was not observed any change in production routines in the system of maturation, only on the delivery mode barrels reported by one respondent in which disassembled parts are purchased and sent to an assembler in Brazil that cater for specific needs of the Miolo. Already in the bottling lines there were no changes in routine due to the expansion of the technical system other than the rearrangement of the organization according to different product lines.

Marketing capabilities of Miolo also went through reformulation. In the last four years, the formation of conglomerate Miolo Wine Group generated structural changes in how the company develops its marketing strategies. Each marketing action is planned based on perceived opportunities by the affiliates, and is expected to be approved by the board of the Miolo Wine Group Institutional Marketing that defines the general guidelines of the company.
The search routines are market research via the regional as well as the marketing department and specialized agencies. Participation in the Wines of Brazil Integrated Program is also a source of information and knowledge on foreign markets as well as participation in international industry fairs and events. The strategies of international marketing and distribution take place through the export department. Prospecting is done through contacts at fairs and importers who also work as consultants to specific regional needs and potential opportunities. Since the start of exports, the company has increased each year the number of countries covered. From the international joint ventures, the company had access to channels of distribution partners and expanded its distribution to 23 countries.

Since 200I, the company serves the entire national territory. By 2006 the company operated with three regional offices to focus their sales through direct selling, online sales representatives, distributors. The company restructured the department of marketing and business strategy in the domestic market. Boards were established focusing on two types of distribution: one focused on retail and other bars and restaurants. For this, we hired new executives to the area seeking to expand both domestic and abroad.

The company has invested in research and development structure. To this end,it installed a laboratory for microbiological analysis and microvinifications. When it comes to research in viticulture, Miolo has a partnership with the Brazilian Enterprise of Agricultural Research (EMBRAPA) and it collaborates with research by providing samples of soil and plants, and at the same time as a way of updating and training its agricultural technicians and winemakers. The company has projects in testing to entry new segments such as organic and biodynamic wines geared toward a more sustainable production. The production of these wines require special care not to use pesticides and pesticides in vineyards and in the case of biodynamic wines, using only natural means totally not made for production.

With regard to research in wine, it was purchased new equipment for the laboratory to help in the perception and sensitivity of the winemaker tasting. These devices are capable of analyzing all elements of wine, acidity, alcohol, color, sugar, $\mathrm{pH}$, density, stratum reduced dry tannins and others. This allows an analysis with extreme precision. 


\subsection{Don Laurindo Winery}

The foundation and the entrance of the winery Don Laurindo in the fine wine market came in 1991 in the midest of a sectoral crisis of the 90s. Now the winery grows its grapes in 15 hectares of its foundation in the Vale dos Vinhedos region and has a winemaking capacity of 120 thousand bottles per year. The winery pursues a strategy of differentiation and seeks to produce wines of value due to quality, methods of preparation and peculiar ways of the owner and chief winemaker. Since its foundation the focus of the commercialization has been restaurants, specialty stores and directly to the consumer at the winery boutique. Based on the patterns of competition observed in the section 4, the company's strategy is quite similar to those of more traditional wineries of the Old World.

\subsection{Macro-analysis}

Since its founding, the company has maintained a small structure of production and a commercial strategy and product identity without much change. The 90 represented to the company a building phase for its winemaking and bottling capability. The winery was the pioneer in bringing some varieties of grape to Brazil. In 1995, the company launched a wine with the Tannat variety. For the winemaker, the winery pioneered the production of a wine as a Assemblage Reserve Wine. He argues that, to the other wineries in the region, the wines made with grapes Assemblage were of poorer quality that remained after harvest. With a reputation built over 90 's, the decade of 2000 served to initiate a process of qualification of wines, and launch the search for new markets. Although the sale is considered passive, ie, the customer is the one who seeks the winery thus requiring little need for a greater sales effort, it can be noticed moves towards the internationalization of wine. In 2004 the company made its first export to the Czech Republic and in 2005 joined the consortium of export Wines from Brazil. Table 4 presents a summary of the innovations and changes in the last two decades.

\begin{tabular}{|l|l|c|}
\hline Year & Main Events & $\begin{array}{c}\text { Types of } \\
\text { innovation/change }\end{array}$ \\
\hline $\begin{array}{l}\text { Decade } \\
\text { of } 1990\end{array}$ & $\begin{array}{l}\text { Construction of the structure to winemaking and bottling } \\
\text { Launch of first wines using newly introduced grapes in the country }\end{array}$ & $\begin{array}{c}\text { PROCESS } \\
\text { PRODUCTS }\end{array}$ \\
\hline $\begin{array}{l}\text { Decade } \\
\text { of } 2000\end{array}$ & $\begin{array}{l}\text { Launch of new wines every two years } \\
\text { First exports } \\
\text { Conversion to trellis system method in vineyards aiming at achieving } \\
\text { better quality } \\
\text { Obtaining of indication of provenance label in wines. } \\
\text { Participation in projects with research centers }\end{array}$ & $\begin{array}{c}\text { PRODUCTS } \\
\text { PROCESS } \\
\text { PROCESS }\end{array}$ \\
\hline
\end{tabular}

Table 4 - Macro-analysis of Don Laurindo Winery 


\subsubsection{Micro-analysis}

Table 5 presents the capabilities and routines Winery Don Laurindo that showed changes over the past four years. The analysis considered the capabilities in viticulture, marketing and research and development.

\begin{tabular}{|c|c|}
\hline $\begin{array}{l}\text { CAPABILITIES and underlying } \\
\text { ROUTINES }\end{array}$ & Change in routines in the last four years?? \\
\hline \multicolumn{2}{|l|}{ VITICULTURE } \\
\hline Soil and Plants Management & Converted to cordon trellis system. \\
\hline \multicolumn{2}{|l|}{ VINIFICATION } \\
\hline $\begin{array}{l}\text { Process of receiving and de-stemming } \\
\text { grapes }\end{array}$ & Remained unchanged \\
\hline $\begin{array}{l}\text { Conduction system, fermentation and } \\
\text { maceration }\end{array}$ & $\begin{array}{l}\text { Change in technical system. The company started to use tangential filtration in } \\
\text { white wine do to international regulations }\end{array}$ \\
\hline Maturation Systems & $\begin{array}{l}\text { Began to use American barrels in addition to the French ones, but did not alter } \\
\text { the routine. }\end{array}$ \\
\hline Bottling process & Remained unchanged. \\
\hline Aging Process in Caves & Remained unchanged. \\
\hline \multicolumn{2}{|l|}{ MARKETING } \\
\hline Marketing Research & \multirow[t]{2}{*}{ Increased participation in international events. } \\
\hline $\begin{array}{l}\text { Communication, promotion and } \\
\text { advertising actions }\end{array}$ & \\
\hline $\begin{array}{l}\text { Marketing Strategies and } \\
\text { distribution }\end{array}$ & Increased exports \\
\hline \multicolumn{2}{|l|}{ PESQUISA E DESENVOLVIMENTO } \\
\hline Research on Viticulture & $\begin{array}{l}\text { Initiated a project along with research institutions aiming at obtaining } \\
\text { appellation of origin }\end{array}$ \\
\hline Research on Vinification & Provides sample to a local university research program. \\
\hline $\begin{array}{l}\text { Research using alternative materials } \\
\text { (packaging, closures, etc.) }\end{array}$ & Does not do. Remained unchanged. \\
\hline Product Development & There was no change in technical systems, repertories, and types of inputs. \\
\hline
\end{tabular}

Table 5 - Micro-analysis of Don Laurindo Winery 
With respect to the production capabilities in viticulture, the routine management of soils and plants with the control system of plant nutrition (fertilizer), control of buds, winter pruning, pruning of green branches and elimination of clusters, aiming to regulate the production, control of pests and diseases, monitoring of maturation, renovation and conversion of vineyards are carried out internally by staff and owners of the company. The more detailed analysis of the raw material is outsourced, as it requires technical systems that the company does not own. The authorization for harvest is carried out by the company through the staff and by the Chief Winemaker.

The main change/innovation capabilities in the wine business over the past four years occurred in the technical system and method of conducting the vines. The company made the conversion of its vineyards to cordon trellis system. As Gollo (2006), the company used the trellis system to be convinced that this system was most suitable for the region, though this belief was apparently undone. The change resulted in reducing the quantity produced in order to increase the quality of the grape.

According to the owner, the wine-making capabilities are unchanged, except for the adoption of the method and system technical tangential filtration in white wines. This adjustment was motivated by the expectation that the owner will become a requirement in white wines for export.

The strategy of marketing, distribution and marketing for the domestic market has remained consistent since its inception. The Company is focused on specialty stores, restaurants, retail and the company's own online sales. The company markets its products primarily in the South and in São Paulo. According to the owner of the selling process that occurs in the company is passive, ie there is no investment in advertising. Prospecting for new customers occurs informally in meetings and confraternities that the winemaker is invited to participate, but is generally a process in which potential customers come in contact with the company.

The major changes occurred in the marketing strategy and distribution for international markets. In 2004 the company made its first export to the Czech Republic through the demand for an importer. In 2005, the winery joined the program Wines from Brazil, which has enabled access to information about foreign markets and participation in fairs and international events. The quest for inclusion in the international market aims to produce positive effects on the perception about the quality of these products in the domestic market and thus adding value to products in the domestic market.

Product development, as well as other processes is centered on the owner and chief winemaker. Research for the development of new wines is basically by trial and observation of results achieved with changes in the previous year.

Given only the aspect of developing new products every season, there was no change of routine in the last four years. The fact the winery develops new wines each year is part of new combinations that make up in the current repertoires of the winemaker and it uses the same technical systems. In this sense, the developing new wines combines different elements that are already known to the winery, in other words, there is change to new routines or capabilities in these specific ones.

With regard to research in viticulture, the company has actively participated in the joint project with EMBRAPA to obtain the appellation of origin label that has an strategic value to the company as it gives credibility to the wine both in Brazil and abroad.

The results indicate that both companies showed changes in the last four years, as well as changes in their routines and capabilities. Thus, although firms develop different strategies associated with different patterns of competition in the wine world (Charters, 2006), it was found that both have changed their routines in order to systematically improve operational efficiency, confirming Zollo and Winter (2002).

The major innovations and changes that occurred in enterprises over the past two decades were in the process according to the classification of Francis and Bessant (2005), ie, the introduction of a new production method, according to Schumpeter (1934). This may be related to product characteristics and the wine industry, classified as a low-technology sector by the OECD (2005).

In the case of Miolo, evidence indicates that the company has developed a strategy of expansion in domestic and international market through various partnerships and joint ventures. Thus, changes occurred in a more intense and accelerated way through the development and improvement $\circ$ capabilities and through multiple paths to innovation. In the Winery Don Laurindo there was 
a concern with maintaining the company's competitive position in the market. In the second case, the highlights are the changes in marketing capabilities and marketing aimed at adding value to the product.

From the identification of changes and/or innovations made by companies in the last four years, the microanalysis allowed the identification of changes in routines that form the production (viticulture and winemaking), marketing and R\&D capabilities. Thus, the empirical results confirm the relationship between routines and innovation capability recommended in the analytical scheme of work based on previous research (Bessant and Francis, 1999; Eisenhardt and Martin, 2000; Peng, Schroeder and Shah, 2007).

In this sense, the analysis of Miolo, it was found that the company has sought to "integrate, build and reconfigure internal and external competences to address changing environments, highlighting the firm's dynamic capability, as Teece, Pisano and Shuen (1997). This dynamic may also occur in Don Laurindo Winery, but differently. The strategic actions and decision making is centralized in the owner and chief winemaker, which prioritizes the tradition of the product. Thus, the changes are aimed at priority, not the operational capability for the production of new products from new capabilities, but creating value in the market.

\section{Conclusions}

This study aimed to examine the relationship between routines, capabilities and innovation, seeking to identify changes and/or innovations that have occurred along the trajectory of the firm and how these changes have altered their routines and capabilities. To that end, we conducted a case study of two companies in the wine sector located in the Serra aucha in Rio Grande do Sul. The analytical framework evaluated the of production, marketing and R\&D capabilities of the firm that are considered important for the innovation process. These capabilities are formed by a set of routines. Thus, changes and/or innovations are related to the changes that occur in their routines and capabilities.

The results indicate that both companies have developed innovations and change their capabilities and routines. These innovations/changes involving the three capabilities were more intense in Miolo Winery. Don Laurindo winery, on the other hand, adopts a more conservative strategy and showed more significant changes in marketing capabilities. However, both companies aim to add value to the end. This search on Don Laurindo Winery is made possible by the pursuit of market differentiation, producing small quantities with a focus on quality and customer loyalty. This strategy has allowed the company to build a reputation and increase its customer base organically. Already Miolo, the winery seeks to add value by offering a wide range of products on the market with 110 labels, which covers different types of products in terms of price and quality. With this the company aims to develop the domestic market and expand its boundaries internationally.

This work offers some theoretical, methodological and managerial contributions. Theoretically, the study attempts to discuss capabilities and dynamic capabilities relating them to the concepts of routines, capabilities and innovation. The analysis method can be used in further studies to investigate the routines and capabilities of the firm. From a microanalysis of the routines and requirements, managers can identify situations in which capabilities have not yet been satisfactory and then search on how to change and improve them as well as examine the different paths for innovation/change aiming at gainning competitive advantage.

As for limitations, the study did not ascertain the impact of various changes to the companies identified in a quantitative manner if not for his own perception of the interviewees in their accounts. Thus, further work could develop a metric that indicates the impact on routines and relevance of the innovations implemented by the firm.

\section{Notas}

I Terroir: French word to denote the special characteristics that the geography, geology and climate of a certain place combined with human characteristics bestowed upon particular varieties.

2 Conduction system and cordon trellis: installation methods used in vines to produce grapes with the aim of obtaining higher or lower concentration of nutrients as well as higher or lower productivity. 


\section{References}

ALIEVI, R. M.; Fensterseifer, J. E. (2007) Relações de cooperação e criação de vantagens competitivas: um estudo no arranjo produtivo vinícola da região da serra gaúcha - Brasil. In: DOTTO, D. M. E., \& Matuelle, Juvir, L. Estudos organizacionais - Desafios Contemporâneos. Santa Cruz: Edunisc.

ANDERSON, E., \& Gatignon, H. (2004) Firms and the creation of new markets. In C. Ménard \& M. M. Shirley (Eds.). Handbook of new institutional economics (pp. 40I-43I). New York: Springer.

ANDERSON, K. (ed.) (2004) The World's Wine Markets: Globalization at Work. Edward Elgar,Cheltenham.

BARNEY, J. (1991) Firm resources and sustained competitive advantage. Journal of Management, I7 (I), 99-120.

BECKER, M. C.; Lazaric, N. (2009) Advancing Empirical Research on Organizational Routines: introduction. In: Organizational Routines: Advancing Empirical Research. Cheltenham: Edward Elgar Publishing Limited; p. I-10.

BESSANT, J., Francis, D. (1999) Developing strategic continuous improvement capability. International Journal of Operations \& Production Management, I9 (II), II06-III9.

CHANDLER, A. D. (1992) Organizational capabilities and the economic history of the industrial enterprise. Journal of Economic Perspectives, 6 (3): 79-100.

CHARTERS, S. (2006) Wine \& Society - the Social and Cultural Context of a Drink, Ist Edition, Elsevier, Butterworth-Heinemann, Oxford.

CHRISTENSEN, C.M. (2003) The innovator's dilemma: the revolutionary book that will change the way you do business. New York: HarperCollins.

COASE, R. (1937) The Nature of the Firm. Economica, New Series, 4 (16), 386-405.

COLLIS, D.J. (1994) Research note: how valuable are organizational capabilities? Strategic Management Journal. $15(8)$, 143-152.
COOPER, R. G. (200I) Winning at New Products: accelerating the process from idea to launch. 3 ed. USA, NY: Basic Book.

DOSI, G., Nelson, R., Winter, S. (Eds.), 2000. The Nature and Dynamics of Organizational Capabilities. New York: Oxford University Press.

EISENHARDT, K.M., Martin, J.A. (2000) Dynamic capabilities: What are they? Strategic Management Journal. 21 (I0/II), II05-II2I.

FAGERBERG, J. (2004). Innovation: A Guide to the Literature..In: Fagerberg, J., Mowery, D.C. \& Nelson, R.. The Oxford Handbook of Innovations. Oxford University Press. pp. I-26.

FRANCIS, D., Bessant, J. (2005) Targeting innovation and implications for capability development. Technovation, $25,|7|-\mid 83$.

FREEMAN, C. (1994) The economics of technical changes. Cambrige Journal of Economics, 18, p.463-5I4.

GLOBAL WINE SUPPLY MONITOR (2009) Market Insight Report. Obtained through the internet: http://www.wineaustralia.com/australia/LinkClick.aspx?fil

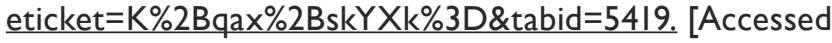
17/03/2010].

GOLLO, S.S. (2006) Inovação e Estratégia de Cooperação Competitiva: estudo de caso da indicação de procedência Vale dos Vinhedos - Serra Gaúcha/RS. 2006. 36I f. Tese (Doutorado em Administração) - Programa de Pós-Graduação em Administração, Escola de Administração, Universidade Federal do Rio Grande do Sul, Porto Alegre.

GRANT, R.M., 199I. The resource-based theory of competitive advantage: implications for strategy formulation. California Management Review, 33 (3), II4-135.

HAYES, R.H. (1985) Strategic planning-forward in reverse? Harvard Business Review, 63(6): I I I-I 19. 
HENDERSON, R., Clark, K. (1990) Architectural innovation: the reconfiguration of existing product technologies and the failure of established firms. Administrative Science Quarterly, 35, 9-30.

MIOLO WINE GROUP (2010) Annual Report. Obtained through the internet: http://www.miolo.com.br. [Accessed $17 / 03 / 2010]$.

NELSON, R. R. (199I) Why do firms differ, and how does it matter? Strategic Management Journal, Winter Special Issue, 12, Pp. 6I-74.

NELSON, R.R., Winter, S.G. (1982) An Evolutionary Theory of Economic Change. Harvard University Press, Cambridge, MA.

OCDE - Organização para Cooperação e Desenvolvimento Econômico. Stan Indicators. OCDE: 2005. http://financasfaceis.files.wordpress.com/2009/10/stanindicators-2005-edition.pdf. [Accessed July 28, 2010]

PENG, D. X., Schroeder, R. G., Shah, R. (2007) Linking routines to operations capabilities: $A$ new perspective. Journal of Operations Management 26, (6), 730-748.

PORTER, M.E. (1998) Clusters and the new economics of competition. Harvard Business Review, 76 (6), nov./dec., 77-90, 1998.

PRAHALAD, C.K., Hamel, G. (1990) The core competence of the corporation. Harvard Business Review, 68 (3), 79-9l.

RICHARDSON, G. B. (1972) The organization of industry. Economic Journal, 82 (September), 883-896.

ROTHWELL, R.;Gardiner, P. (1985) Invention, Innovation, reinnovation and the role of the user. Technovation, 3, 167-186.

SCHUMPETER, J. A. (1934) The Theory of Economic Development. Cambride: Harvard University Press. First published in German, 1912.

STALK, G.; Evans, P.; Shulman, L.E. (1992) Competing on capabilities: The new rules of corporate strategy. Harvard Business Review, 70(2): 57-69.
STERNS, J. A.; Schweikhardt, D. B.; Peterson, H. C. (1998) Using case studies as an approach for conducting agribuisiness research. International Food and Agribusiness Management Review, I, 3, p. 3II-327.

TEECE, D.J., Pisano, G., Shuen, A. (1997) Dynamic capabilities and strategic management. Strategic Management Journal, 18 (7), 509-533.

UNWIN, T. (1996) Wine and the Vine: An Historical Geography of Viticulture and the Wine Trade. London: Routledge.

UTTERBACK, J. E.; Abernathy, W. (1975) A dynamic model of process and product innovation, Omega 3, 639-656.

WANG, C. E Ahmed, P. (2007). Dynamic capabilities: a review and research agenda. International Journal of Management Review, 9 (I) , 3I-5I.

WHEELWRIGHT, S.; Clark, K. (1992) Revolutionising Product Development. New York: Free Press.

WILLIAMSON, O.E. (1985). The Economic Institutions of Capitalism. New York, Free Press.

WINTER, S.G. (2000) The satisficing principle in capability learning. Strategic Management Journal. 2I, 98I-996.

YIN, R. K. (2003) Case study research: Design and methods (3rd ed.). Newbury Park, CA: Sage.

ZOLLO, M.;Winter, S.G. (2002) Deliberate learning and the evolution of dynamic capabilities. Organization Science, 13 (3), 339-35I. 
J. Technol. Manag. Innov. 20II,Volume 6, Issue 2 